\title{
West Nile virus lineage 2 isolated from Culex modestus mosquitoes in the Czech Republic, 2013: expansion of the European WNV endemic area to the North?
}

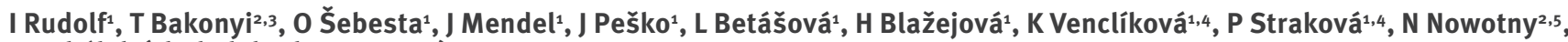

Z Hubálek (zhubalek@brno.cas.cz) ${ }^{1}$

1. Institute of Vertebrate Biology, Academy of Sciences, v.v.i., Brno, Czech Republic

2. Viral Zoonoses, Emerging and Vector-Borne Infections Group, Institute of Virology, University of Veterinary Medicine, Vienna, Austria

3. Department of Microbiology and Infectious Diseases, Faculty of Veterinary Science, Szent István University, Budapest, Hungary

4. Department of Experimental Biology, Faculty of Science, Masaryk University, Brno, Czech Republic

5. Department of Microbiology and Immunology, College of Medicine and Health Sciences, Sultan Qaboos University, Muscat, Oman

Citation style for this article:

Rudolf I, Bakonyi T, Šebesta O, Mendel J, Peško J, Betášová L, Blažejová H, Venclíková K, Straková P, Nowotny N, Hubálek Z. West Nile virus lineage 2 isolated

from Culex modestus mosquitoes in the Czech Republic, 2013: expansion of the European WNV endemic area to the North?. Euro Surveill. 2014;19(31):pii=20867.

Available online: http://www.eurosurveillance.org/ViewArticle.aspx?Articleld=20867

Article submitted on 24 July 2014 / published on 07 August 2014

We report the detection and isolation of four almost identical strains of West Nile virus (WNV) lineage 2 from Culex modestus mosquitoes collected at three fish ponds in South Moravia, Czech Republic, during August 2013. Phylogenetic analysis demonstrated that the Czech WNV strains isolated are closely related to Austrian, Italian and Serbian strains reported in 2008, 2011 and 2012, respectively. Our findings show the current northernmost range of lineage 2 WNV in Europe.

In South Moravia in the Czech Republic, surveillance activities for mosquitoes and mosquito-borne pathogens have been carried out for several decades, but until our findings in 2013 presented here, WNV lineage 2 (WNV-2) had not been detected.

\section{Background}

WNV is a mosquito-borne virus (genus Flavivirus; family Flaviviridae) that is widely distributed in Africa, the Middle East, Asia and southern Europe [1] and was recently introduced in the Americas [2]. WNV circulates in natural foci between birds (as amplifying hosts) and bird-feeding mosquitoes, in Europe principally Culex pipiens and $C x$. modestus [3]. Humans and horses are considered accidental dead-end hosts. Most individuals infected with WNV are asymptomatic. Symptoms may develop in $20-40 \%$ of people with WNV infection, most frequently characterised as influenza-like symptoms, (West Nile fever (WNF)). Less than $1 \%$ of infected individuals develop severe neuroinvasive disease, which can be classified into three main clinical syndromes: West Nile meningitis, West Nile encephalitis and acute flaccid paralysis [4].

Several human and/or equine WNF outbreaks have occurred in the last decades in Europe, for example, in Romania (1996), Italy (1998) and Russia (1999) [1].
From 2008 onwards, an unexpected explosive spread of WNV-2, which resulted in several hundreds of human neuroinvasive cases, has been documented in Hungary, Greece and Serbia [5-7].

In the Czech Republic, three identical strains of WNV (proposed genomic lineage 3: Rabensburg) were isolated from Cx. pipiens and Aedes rossicus mosquitoes in 1997, 1999 and 2006 [8,9]. Although neutralising antibodies against WNV have been found rarely in humans in the Czech Republic, two confirmed cases of WNF in humans were reported after heavy floods in 1997 [10]. In addition, WNV-specific antibodies have been detected in resident wild bird species [11]. The above rare traces of WNV infections in the Czech Republic before 2008 were most likely due to WNV lineage 1. Sera collected from 163 horses, originating from 43 out of 77 administrative districts of the Czech Republic between 2008 and 2011, all proved negative for WNV antibodies [12]. Because of the rapidly changing epidemiological situation regarding WNF in Europe, we decided to perform virological surveillance of mosquitoes for WNV and related pathogenic flaviviruses (e.g. Usutu virus) to investigate the epidemiological relevance of WNF in the Czech Republic.

\section{Study site}

In this study, mosquitoes were collected within reed belts (Phragmition communis alliance) of the fish ponds 'Nesyt' (48 ${ }^{\circ} 46^{\prime} 35^{\prime \prime} \mathrm{N}, 16^{\circ}$ 42'05' E; $176 \mathrm{~m}$ above sea level (a.s.l.)) and 'Nový' (48 '46'57'N, 16 '40'13'”E; $177 \mathrm{~m}$ a.s.l.) at Mikulov, and the fish pond 'Mlýnský' at Lednice (48 47'19'”N, $16^{\circ}$ 49'2'”E; 175 $\mathrm{m}$ a.s.l.) during July and August 2013 (Figure 1). The climate at the ponds is relatively warm and dry: the mean annual air temperature is $9.1^{\circ} \mathrm{C}$ (January $-1.8^{\circ} \mathrm{C}$, July $19.2{ }^{\circ} \mathrm{C}$ ); the mean annual precipitation is $571 \mathrm{~mm}$ 


\section{FIGURE 1}

Locations of three study sites for Culex modestus trapping, South Moravia, Czech Republic, July-August 2013

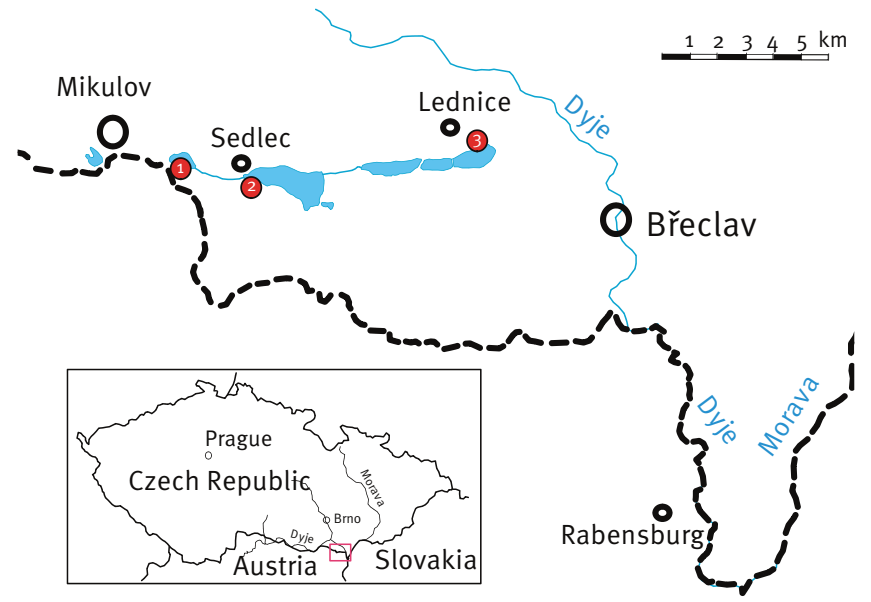

Fish ponds:

1 Nový

2 Nesyt

3 Mlýnský

(range: 284-919 $\mathrm{mm}$ ) (data purchased from the Czech Hydrometeorological Institute). A total of 30 species of birds have been recorded breeding in the reed belts; 51 other avian species breed in the close surroundings of the ponds and an additional 54 wild wetland and terrestrial bird species visit this habitat during their seasonal movements. Mosquitoes in South Moravia comprise 30 species of the genera Anopheles, Aedes, Ochlerotatus, Culex, Culiseta, Coquillettidia and Uranotaenia [13].

\section{Mosquito collection, molecular screening and virus isolation attempts}

Mosquitoes were captured using $\mathrm{CDC}$ minilight- $\mathrm{CO}_{2}$ baited traps (EVS $\mathrm{CO}_{2}$ Mosquito Trap, BioQuip Products, Inc., United States) placed at a height of approximately $1 \mathrm{~m}$ above the ground. The traps were run on two successive nights at two-week intervals. The caught insects were transported to the laboratory of the Institute of Vertebrate Biology, Brno, Czech Republic, in cooled flasks $\left(4\right.$ to $8{ }^{\circ} \mathrm{C}$ ) and stored at $-65^{\circ} \mathrm{C}$ until examination. They were identified under a stereomicroscope and monospecific pools consisting of $50 C x$. modestus females were homogenised in $1.5 \mathrm{ml}$ cooled phosphate buffered saline $\mathrm{pH} 7.4$ supplemented with $0.4 \%$ bovine serum albumin (Sigma) and antibiotics (PBS-BSA) and centrifuged.

Viral RNA was extracted from $140 \mu$ mosquito homogenates using the QIAamp Viral RNA Mini Kit (Qiagen, Hilden, Germany). Oligonucleotide primers targeting the $\mathrm{NS}_{5}$ region of flaviviruses were used for screening [14]. If samples were positive, a set of WNV-specific primers were used in continuous reverse transcription (RT)-PCRs for amplification of overlapping genome fragments that covered the entire genome sequences of the detected viruses [15]. Amplification products were sequenced directly (Microsynth, Balgach, Switzerland), sequences were aligned and compiled, and identified by basic local alignment search tool (BLAST) search against the GenBank database. The WNV sequences were aligned with 25 complete or nearly complete lineage 2 WNV sequences deposited in GenBank database. Phylogenetic and molecular evolutionary analyses were conducted using neighbor-joining and maximum likelihood algorithms (MEGA version 6 [16], with 1,000 replicates for bootstrap testing) and inferred genetic relationships were shown in a phylogram.

Mosquito homogenates of WNV PCR-positive samples $(20 \mu \mathrm{l})$ were inoculated intracerebrally into specified pathogen-free suckling ICR mice (SM). The brains of SM that succumbed to the infection were homogenised in PBS-BSA, centrifuged and passaged (intracerebrally) in a new batch of SM. Bacterial sterility of the suspensions was checked in meat-peptone and thioglycollate broths incubated at $37{ }^{\circ} \mathrm{C}$ [9].

\section{West Nile virus prevalence in Culex modestus mosquitoes}

A total of 32,500 female $C x$. modestus mosquitoes in 650 pools were examined for flaviviruses by RT-PCR. RNA of lineage 2 WNV was detected in four pools of insects collected in August 2013: number 13-104 (collected at Nový fish pond), number 13-329 (collected at Nesyt fish pond), number 13-479 (collected at Mlýnský fish pond) and number 13-502 (collected at Mlýnský fish pond). The minimum prevalence rate of WNV in the examined mosquito pools was therefore $1: 8,125$ (0.012\%). All WNV-2-positive mosquito homogenates were inoculated into SM. While number 13-329 did not kill any mice, the three others did: number $13-104$ killed 6 of 11 inoculated SM within 7-8 days post inoculation (DPI) and the average survival time (AST) of SM was 7.7 days; number $13-479$ killed 8 of 9 inoculated SM (6-7 DPI; AST 6.1 days); and number 13-502 killed 7 of 10 SM (6-8 DPI; AST 6.4 days). Interestingly, experimentally non-infected mothers of mice inoculated with homogenates from all three infective pools succumbed to infection seven to eight days after cannibalising their dead SM, and WNV was demonstrated by realtime RT-PCR in high concentration ( $10^{7}$ RNA copies $/ \mathrm{ml}$ ) in the mothers' brains but not in their livers or spleens. This finding supports the hypothesis of oral infection as a (rare) alternative route of WNV transmission, for example, in raptors.

Phylogenetic analysis based on complete WNV-2 genome sequences demonstrated that the four Czech WNV strains identified form two closely related groups: number 13-104 (GenBank: KM203860) with number 13-502 (GenBank: KM203863) and number 13-329 (GenBank: KM203861) with number 13-479 (GenBank: KM203862) and that they cluster together with WNV strains from an Austrian goshawk (isolated in 2008; GenBank: KF179640), Serbian Cx. pipiens (in 2012; GenBank: KC 407673) and Italian human (in 2011; GenBank: JN858070), while they differ partially from 
Phylogenetic positioning of four West Nile virus strains identified in Culex modestus mosquitoes, South Moravia, Czech Republic, August 2013

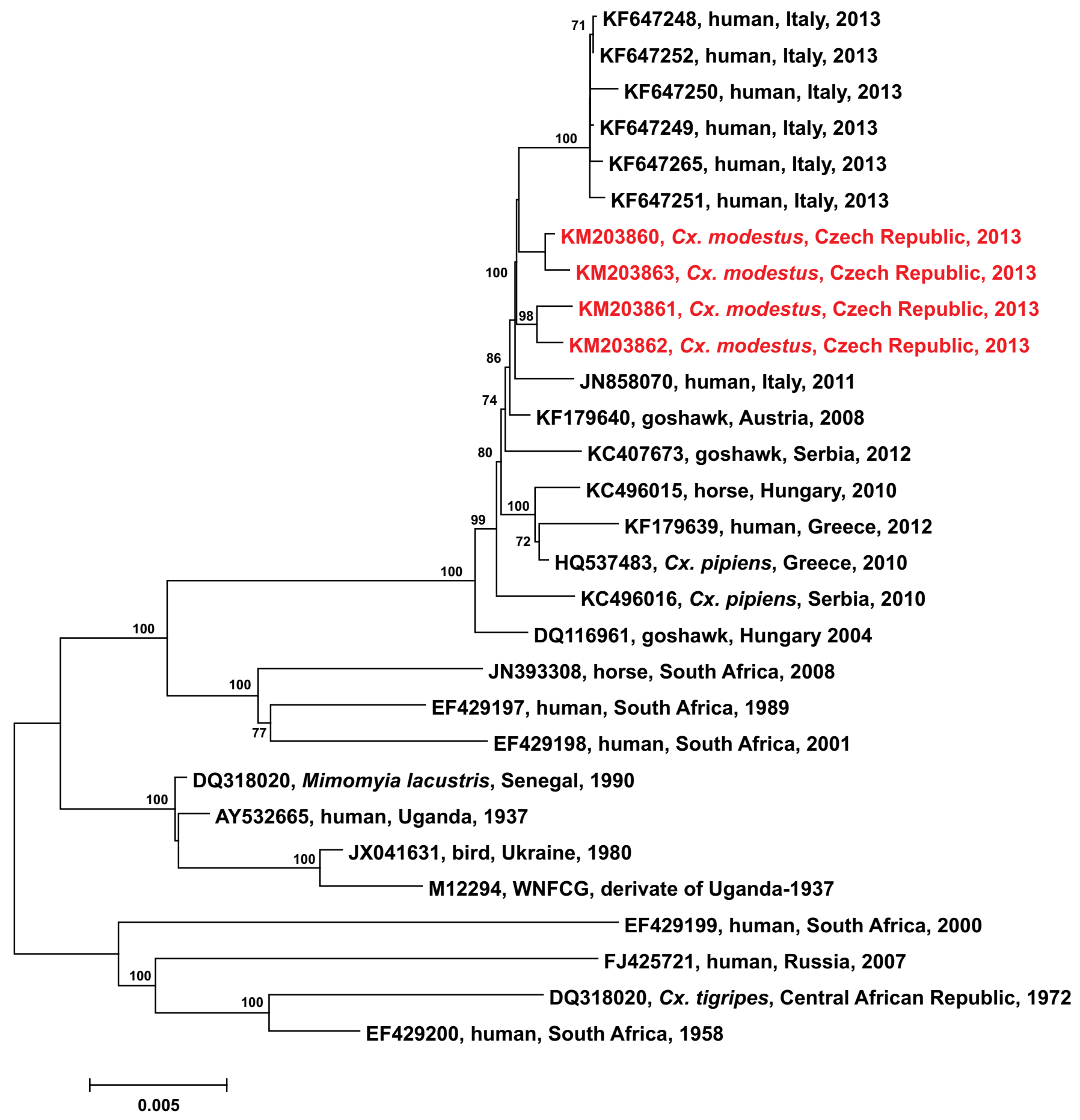

The complete genome nucleotide sequences of the four WNV strains from the Czech Republic (marked in red) were analysed together with representative lineage 2 WNV strains by the neighbor-joining method. GenBank accession numbers, isolation sources, countries of origins and isolation years are indicated at the branches. Supporting (>70\%) bootstrap values of 1,000 replicates are displayed at the nodes. The horizontal bar shows genetic distance. 
other European WNV-2 strains compared. However, they are all in the same clade (i.e. central and south European WNV-2), while WNV-2 strains from Africa and Russia form distinct clades (Figure 2). Maximum likelihood analysis resulted in a similar tree topology. Although three of the four Czech isolates were found to be neuropathogenic in SM, these virus strains do not carry the putative virulence marker P249 within the NS3 region $[17,18]$.

\section{Conclusions}

The discovery of WNV-2 in the Czech Republic has added another country to the list of WNV risk areas in Europe. It also shows that two different lineages of WNV (lineages 2 and 3) co-circulate in the country and that $C x$. modestus mosquito is a potential vector of WNV in reed belts of South Moravian fish ponds. This ornithophilic mosquito might play an important role in the bird-mosquito cycle of WNV in central Europe.

Our study highlights the need for epidemiological surveillance of (re-)emerging mosquito-borne viruses in central Europe. The seasonal peak activity of the adult $C X$. modestus population in central Europe is from the beginning of July to late September [19]. Usually, the females do not enter buildings, but readily bite humans outdoors often during the day, at sun- and wind-exposed places, causing a nuisance, especially in late summer when floodwater Aedes and Ochlerotatus mosquito species have already vanished [19]. The isolation of neuroinvasive WNV strains in South Moravian fish ponds (in a popular recreational and camping area during the summer) raises the question of a possible risk of a local WNF outbreak. Given the mild climate of the 2013-14 winter, we can only speculate on the possible emergence of WNF in this year's WNV season, if favourable conditions for mass breeding of mosquitoes occur. To date, no human WNF cases have been recorded this season, which has just begun (the WNV season in central Europe starts mid-July and the majority of cases are seen in September). While infectious disease specialists in the region are aware of the WNV situation, local general practitioners should also be aware of the circulation of WNV in this area and take it into account during differential diagnosis of late-summer neuroinfections.

\section{Acknowledgements}

This study was funded by the European Union grant FP7261504 EDENext. The publication is catalogued by the EDENext Steering Committee as EDENext244.

\section{Conflict of interest}

None declared.

\section{Authors' contributions}

IR, ZH: designed, coordinated and supervised the study, performed laboratory testing, and wrote the manuscript; TB, JM: carried out sequence analysis, processed phylogenetic data, read and revised the manuscript; $L B, H B$, JP, PS, KV: trapped the mosquitoes, performed molecular analyses, read and revised the manuscript; OS: trapped the mosquitoes and performed their identification, read and revised the manuscript; $\mathrm{NN}$ : analysed data, wrote and revised the manuscript.

\section{References}

1. Hubálek Z, Halouzka J. West Nile fever - a reemerging mosquito-borne viral disease in Europe. Emerg Infect Dis. 1999;5(5):643-50. http://dx.doi.org/10.3201/eido505.990506

2. Jia XY, Briese T, Jordan I, Rambaut A, Chi HC, Mackenzie JS, et al. Genetic analysis of West Nile New York 1999 encephalitis virus. Lancet. 1999;354(9194):1971-2. http://dx.doi. org/10.1016/S0140-6736(99)05384-2

3. Hubálek Z. European experience with the West Nile virus ecology and epidemiology: could it be relevant for the New World? Viral Immunol. 2000;13(4):415-26. http://dx.doi. org/10.1089/vim.2000.13.415

4. Kramer LD, Li J, Shi PY. West Nile virus. Lancet Neurol. 2007;6(2):171-81. http://dx.doi.org/10.1016/ S1474-4422(07)70030-3

5. Bakonyi T, Ferenczi E, Erdélyi K, Kutasi O, Csörgő T, Seidel B, et al. Explosive spread of a neuroinvasive lineage 2 West Nile virus in Central Europe, 2008/2009. Vet Microbiol. 2013;165(12):61-70. http://dx.doi.org/10.1016/j.vetmic.2013.03.005

6. Pervanidou D, Detsis M, Danis K, Mellou K, Papanikolaou E, Terzaki I, et al. West Nile virus outbreak in humans, Greece, 2012: third consecutive year of local transmission. Euro Surveill. 2014;19(13): $\mathrm{pii}=20758$.

7. Popović N, Milošević B, Urošević A, Poluga J, Lavadinović L, Nedelijković J, et al. Outbreak of West Nile virus infection among humans in Serbia, August to October 2012. Euro Surveill. 2013;18(43): pii=20613.

8. Bakonyi T, Hubálek Z, Rudolf I, Nowotny N. Novel flavivirus or new lineage of West Nile virus, Central Europe. Emerg Infect Dis. 2005;11(2):225-31. http://dx.doi.org/10.3201/ eid1102.041028

9. Hubálek Z, Rudolf I, Bakonyi T, Kazdová K, Halouzka J, Sebesta O, et al. Mosquito (Diptera: Culicidae) surveillance for arboviruses in an area endemic for West Nile (lineage Rabensburg) and Tahyna viruses in Central Europe. I Med Entomol. 2010;47(3):466-72. http://dx.doi.org/10.1603/ ME09219

10. Hubálek Z, Savage HM, Halouzka J, Juřicová Z, Sanogo YO, Lusk S. West Nile virus investigations in South Moravia, Czechland. Viral Immunol. 2000;13(4):427-33. http://dx.doi.org/10.1089/ vim.2000.13.427

11. Hubálek Z, Halouzka J, Juřicová Z, Šikutová S, Rudolf I, Honza $M$, et al. Serologic survey of birds for West Nile flavivirus in southern Moravia (Czech Republic). Vector Borne Zoonotic Dis. 2008;8(5):659-66. http://dx.doi.org/10.1089/vbz.2007.0283

12. Hubálek Z, Ludvíková E, Jahn P, Treml F, Rudolf I, Svobodová $P$, et al. West Nile virus equine serosurvey in the Czech and Slovak Republics. Vector Borne Zoonotic Dis. 2013;13(10):7338. http://dx.doi.org/10.1089/vbz.2012.1159

13. Šebesta O, Gelbič I, Minář J. Mosquitoes (Diptera: Culicidae) of the Lower Dyje River Basin (Podyjí) at the Czech-Austrian border. Cent Eur J Biol. 2012;7(2):288-98. http://dx.doi. org/10.2478/s11535-012-0013-8

14. Scaramozzino N, Crance JM, Jouan A, DeBriel DA, Stoll F, Garin D. Comparison of flavivirus universal primer pairs and development of a rapid, highly sensitive heminested reverse transcription-PCR assay for detection of flaviviruses targeted to a conserved region of the NS 5 gene sequences. $J$ Clin Microbiol. 2001;39(5):1922-7. http://dx.doi.org/10.1128/ JCM.39.5.1922-1927.2001

15. Bakonyi T, Ivanics E, Erdélyi K, Ursu K, Ferenczi E, Weissenböck $\mathrm{H}$, et al. Lineage 1 and 2 strains of encephalitic West Nile virus, central Europe. Emerg Infect Dis. 2006;12(4):618-23. http:// dx.doi.org/10.3201/eid1204.051379

16. Tamura K, Stecher G, Peterson D, Filipski A, Kumar S. MEGA6: Molecular Evolutionary Genetics Analysis version 6.0. Mol Biol Evol. 2013;30(12):2725-9. http://dx.doi.org/10.1093/molbev/ mst197

17. Brault AC, Huang CY, Langevin SA, Kinney RM, Bowen RA, Ramey WN, et al. A single positively selected West Nile viral mutation confers increased virogenesis in American crows. Nat Genet. 2007;39(9):1162-6. http://dx.doi.org/10.1038/ng2097

18. Papa A, Bakonyi T, Xanthopoulou K, Vázquez A, Tenorio A, Nowotny N. Genetic characterization of West Nile virus lineage 2, Greece, 2010. Emerg Infect Dis. 2011; 17(5):920-2. http:// dx.doi.org/10.3201/eid1705.101759

19. Becker N, Petrič D, Zgomba M, Boase C, Madon M, Dahl C, et al. Mosquitoes and their control, 2nd ed. Heidelberg: Springer; 2010. http://dx.doi.org/10.1007/978-3-540-92874-4 